\title{
Fatal toxoplasmosis in an immunosuppressed domestic cat from Brazil caused by Toxoplasma gondii clonal type I
}

\author{
Toxoplasmose fatal em um gato doméstico imunossuprimido do Brasil causada por \\ Toxoplama gondii clonal tipo I
}

Hilda Fátima de Jesus Pena ${ }^{1 *}$; Camila Mariellen Evangelista²; Renata Assis Casagrande ${ }^{2}$; Giovana Biezus²; Claudia Salete Wisser²; Paulo Eduardo Ferian²; Anderson Barbosa de Moura²; Veronica Machado Rolim³; David Driemeier ${ }^{3}$; Solange Oliveira ${ }^{1}$; Bruna Farias Alves ${ }^{1}$; Solange Maria Gennari ${ }^{1}$; Sandra Davi Traverso ${ }^{2}$

\begin{abstract}
${ }^{1}$ Departamento de Medicina Veterinária Preventiva e Saúde Animal, Faculdade de Medicina Veterinária e Zootecnia - FMVZ, Universidade de São Paulo - USP, São Paulo, SP, Brasil

${ }^{2}$ Departamento de Medicina Veterinária, Centro de Ciências Agroveterinárias - CAV, Universidade do Estado de Santa Catarina UDESC, Lages, SC, Brasil

${ }^{3}$ Departamento de Patologia Clínica, Faculdade de Veterinária - FaVet, Universidade Federal do Rio Grande do Sul - UFRGS, Porto Alegre, RS, Brasil
\end{abstract}

Received February 4, 2017

Accepted April 10, 2017

\begin{abstract}
The objective of the study was to report on a fatal case of feline toxoplasmosis with coinfection with the feline leukemia virus (FeLV). A domestic cat (Felis silvestris catus) presented intense dyspnea and died three days later. In the necropsy, the lungs were firm, without collapse and with many white areas; moderate lymphadenomegaly and splenomegaly were also observed. The histopathological examination showed severe necrotic interstitial bronchopneumonia and mild necrotic hepatitis, associated with intralesional cysts and tachyzoites of Toxoplasma gondii that were positive by anti- $T$. gondii immunohistochemical (IHC) evaluation. The bone marrow showed chronic myeloid leukemia and the neoplastic cells were positive by anti-FeLV IHC evaluation. DNA extracted from lungs was positive for $T$. gondii by PCR targeting REP-529. T. gondii was characterized by PCR-RFLP and by the microsatellites technique. ToxoDB-PCR-RFLP \#10, i.e. the archetypal type I, was identified. Microsatellite analysis showed that the strain was a variant of type I with two atypical alleles. This was the first time that a $T$. gondii clonal type I genotype was correlated with a case of acute toxoplasmosis in a host in Brazil.
\end{abstract}

Keywords: Felis silvestris catus, FeLV, genotyping, immunohistochemistry, microsatellite markers.

\section{Resumo}

O objetivo deste estudo foi relatar um caso de toxoplasmose felina fatal com coinfecção com o vírus da leucemia felina (FeLV). Um gato doméstico (Felis silvestris catus) apresentou intensa dispneia e morreu três dias depois. Na necropsia, observaram-se pulmôes firmes, não colabados e com múltiplas áreas brancas, além de linfoadenomegalia e esplenomegalia moderadas. No exame histopatológico, evidenciaram-se broncopneumonia intersticial necrótica acentuada e hepatite necrótica discreta associada a cistos e taquizoítas de T. gondii intralesionais positivos na imuno-histoquímica (IHC) anti-T. gondii. Evidenciou-se ainda, na medula óssea, leucemia mieloide crônica com IHC anti-FeLV positiva nas células neoplásicas. O DNA extraído dos pulmóes foi positivo para T. gondii por meio da PCR-REP-529. T. gondii foi caracterizado por PCR-RFLP e pela técnica de microssatélites. Foi identificado o genótipo ToxoDB-PCR-RFLP \#10, i.e., o arquétipo tipo I. A análise por microssatélites mostrou que a cepa era uma variante do tipo I, com dois alelos atípicos. Esta é a primeira vez que T. gondii clonal tipo I foi relacionado com um caso agudo de toxoplasmosis em um hospedeiro no Brasil.

Palavras-chave: Felis silvestris catus, FeLV, genotipagem, imunohistoquímica, marcadores microssatélites.

\footnotetext{
*Corresponding author: Hilda Fátima de Jesus Pena. Laboratório de Doenças Parasitárias, Departamento de Medicina Veterinária Preventiva e Saúde Animal - VPS, Faculdade de Medicina Veterinária e Zootecnia, Universidade de São Paulo - USP, Avenida Prof. Dr. Orlando Marques de Paiva, 87, Cidade Universitária, CEP 05508-270, São Paulo, SP, Brasil. e-mail: hfpena@usp.br
} 


\section{Introduction}

Toxoplasmosis is a cosmopolitan infection disease caused by the obligate intracellular protozoon Toxoplasma gondii. Domestic cats and wild felids are the only definitive hosts and they can excrete the oocysts in their feces after infection. All homeothermic animals serve as intermediate hosts, including humans (DUBEY, 2010).

In Brazil, the prevalence of anti-T. gondii antibodies varies between different regions, with reports of $19.5 \%$ in the state of Rio de Janeiro (GONÇALVES et al., 2003), 35.4\% in the state of Sáo Paulo (PENA et al., 2006), 16.3\% in Paraná (CRUZ et al., 2011) and 14.33\% in Santa Catarina (ROSA et al., 2010). There are many reasons for these variations, including the cat population sampled (stray or owned), sampling, age of cats, density of cats, environmental contamination with oocysts, $T$. gondii seroprevalence in small animals (such as rodents), serological test and cutoff titers used. In France, seroprevalence in cats was correlated with the weather, such that it was the highest with hot and humid weather or moderate-temperature and drier weather (AFONSO et al., 2006).

Concomitant infection with viral agents from cats has been correlated with the seroprevalence of T. gondii. Lucas et al. (1998) demonstrated that there is a strong association $(p<0.05)$ between serological findings of infection by the feline immunodeficiency virus (FIV) and the presence of T. gondii. Dorny et al. (2002) found that cats seropositive for FIV had higher antibody titers than did FIV-negative cats, but these associations were not found with the feline leukemia virus (FeLV). A recent review on T. gondii and concurrent infection with FIV and FeLV concluded that there is no evidence for this kind of association (DUBEY et al., 2009).

Infection by $T$. gondii in cats is generally subclinical and most cats do not develop clinical abnormalities (LAPPIN, 2010). However, fatal systemic cases have been reported in immunocompetent cats (SPYCHER et al., 2011; JOKELAINEN et al., 2012; NAGEL et al., 2013; COHEN et al., 2016) and in immunocompromised cats after administration of immunosuppressant drugs (LAST et al., 2004) and kidney transplantation (BERNSTEEN et al., 1999). Coinfection with immunosuppressant retroviruses such as FIV has also been reported to be a risk factor for development of a clinical condition of toxoplasmosis (DAVIDSON et al., 1993). Nonetheless, experimental FeLV infection before T. gondii challenge in cats did not cause acute toxoplasmosis or excretion of oocysts (PATTON et al., 1991).

In South American countries, including Brazil, the T. gondii population has high genetic diversity (AJZENBERG et al., 2004; LEHMANN et al., 2006; PENA et al., 2008) and the globally distributed archetypal clonal genotypes types I, II and III (HOWE \& SIBLEY, 1995) occur at low frequencies, particularly types I and II (SHWAB et al., 2014). From 106 previously identified genotypes, corresponding to 385 Brazilian strains, which were included in the geographical patterns of $T$. gondii studied by Shwab et al. (2014), two were type I clonal, one was type II clonal, five were type II variant, six were type III clonal (ToxoDB RFLP \#10, \#1, $\# 3$ and \#2) and 92 were non-archetypal genotypes. Besides being highly diverse, most of the strains isolated in Brazil are virulent towards mice, thus differing from those in North America and Europe (PENA et al., 2008).
It is of epidemiological interest to report on $T$. gondii genotypes that are associated with clinical disease in different hosts and regions. The objective of the present study was to report on the clinical, anatomopathological, immunohistochemical and molecular characterization findings relating to $T$. gondii in a fatal case of toxoplasmosis in an immunosuppressed domestic cat that presented leukemia due to infection by the feline leukemia virus.

\section{Material and Methods}

A short-furred five-year-old male domestic cat (Felis silvestris catus) without any defined breed, which had not been vaccinated or dewormed, was attended at the Veterinary Clinical Hospital of the University of Santa Catarina State (UDESC), state of Santa Catarina, southern Brazil, in March 2015. It had respiratory signs and subsequently died. Epidemiological data were obtained during the clinical consultation. The animal was necropsied and samples were collected from organs, including encephalon, lung, heart, skeletal muscle, liver, kidney, bladder, adrenal gland, thyroid, spleen, lymph nodes (mandibular, axillary, mediastinal, tracheobronchial, epigastric, hepatic, perirenal, mesenteric and popliteal), bone marrow, stomach and intestines. They were fixed in $10 \%$ buffered formalin and routinely processed for histological evaluation, with staining using the hematoxylin-eosin (HE) method. Lung fragments were frozen at $-20{ }^{\circ} \mathrm{C}$ for subsequent molecular study.

Immunohistochemical (IHC) evaluation was performed on the lung tissue to detect $T$. gondii using a polyclonal antibody $\left(\mathrm{VMRD}^{\circledR}\right.$, at dilution 1:1000) with $0.1 \%$ trypsin for 10 minutes for antigen retrieval, and also a modified avidin-biotin peroxidase complex method (LSAB-HRP kit, DakoCytomation ${ }^{\circledR}$ ) using diaminobenzidine (DakoCytomation ${ }^{\circledR}$ ) as the chromogen; lung tissue from a dog with toxoplasmosis was used as the positive control. IHC analysis was performed on the bone marrow to detect the feline leukemia virus (FeLV) and feline immunodeficiency virus (FIV) using a monoclonal antibody $\left(\right.$ Serotec $^{\circledR}$, at dilution 1:500 and 1:100, respectively) with Tris EDTA buffer $\mathrm{pH} 9.0$ (FeLV) and $0.01 \mathrm{M}$ citrate buffer $\mathrm{pH} 6.0$ (FIV), for $40 \mathrm{~min}$ at $100{ }^{\circ} \mathrm{C}$ for antigen retrieval, and also streptavidin biotin alkaline phosphatase (LSAB-AP kit, DakoCytomation ${ }^{\circledR}$ ) using permanent red (DakoCytomation ${ }^{\circledR}$ ) as the chromogen. Previously confirmed positive FeLV and FIV positive controls were analyzed simultaneously with the tested samples.

For molecular detection of the agent, PCR targeting a repeated $529 \mathrm{bp}$ fragment of the genome of $T$. gondii was used in accordance with the protocol of Homan et al. (2000). The positive control consisted of DNA extracted from tachyzoites of the RH reference strain of $T$. gondii. PCR-RFLP was performed using 11 distinct markers: SAG1, SAG2 (5'3'SAG2 and alt. SAG2), SAG3, BTUB, GRA6, c22-8, c29-2, L358, PK1, Apico and CS3. DNA from tachyzoites from archetypal clonal strains (Type I-GT1, Type II-PTG and Type III-CTG) and reference strains (TgCgCa1-Cougar, MAS and $\mathrm{TgCatBr5}$ ) were used as positive controls. The protocols for amplification, enzymatic digestion and analysis of the fragments were as previously described (SU et al., 
2010; PENA et al., 2008). The causative strain was classified in accordance with the genotypes present on the ToxoDB platform (GAJRIA et al., 2007) and in recent publications, from 2014 to March 2017, that were retrieved from the PubMed (NCBI, 1988) and ScienceDirect ${ }^{\circledR}$ (SCIENCE DIRECT, 2017) databases.

The strain analyzed was also genotyped by means of 15 microsatellite (MS) markers: TUB2, W35, TgMA, B18, B17, M33, IV.1 and X1.1 (typing markers); and N60, N82, AA, N61, N83, M48 and M102 (fingerprinting markers), in accordance with the protocols of Ajzenberg et al. (2010), so as to increase the resolution of the genotyping. The positive control used was the DNA from tachyzoites of the PTG strain. The analysis on the results was done using the Genemapper ${ }^{\circledR} 4.1$ software (Applied Biosystems). The Neighbor-Joining tree was reconstructed from microsatellite data only. The unrooted tree was reconstructed using Populations 1.2.32 (LANGELLA, 1999) based on Cavalli-Sforza and Edwards chord-distance estimator (CAVALLI-SFORZA \& EDWARDS, 1967) and generated with MEGA version 7.0.18 (KUMAR et al., 2016). In order to verify the phylogenetic relationships among the strain studied and others that have been reported, and analyzed by MS markers, clonal type I strains from South and Central America and one from a human patient in Europe were chosen.

\section{Results}

The clinical signs presented by the cat were severe dyspnea and tachypnea, which evolved over a 24-hour period. However, the cat had been prostrated and hyporexic for a week, with episodes of sneezing. It had been living with several other cats, with free access to the streets and had the habit of hunting rodents. In view of the patient's condition, chest radiography and hematological evaluation were requested after stabilization had been achieved. The radiograph revealed bronchoalveolar pneumopathy and alveolar opacification in cranial pulmonary lobes. The hematological evaluation demonstrated mild leukopenia and marked lymphopenia
(Table 1). From then onwards, the suspected diagnosis became feline asthma or chronic bronchitis in association with secondary pneumonia. The cat was then interned and subjected to oxygen therapy, intravenous antibiotic therapy (ampicillin with sulbactam) and administration of bronchodilators (terbutaline sulfate). No clinical improvement occurred and the cat died two days after internment.

In the necropsy examination, the cat presented pallid mucosa and moderate dehydration. The lungs were firm, without collapse, and had many white areas interspersed with reddened areas. Upon cutting, serous fluid came out of the bronchi (Figure 1A). The mediastinal lymph nodes and spleen were moderately enlarged, and the parenchyma of the spleen presented many whitened points.

The histological lesions observed in the lungs were due to diffuse interstitial pneumonia with hyperplasia of type II pneumocytes. There was multifocal fibrinoid necrosis of alveoli and bronchioles associated with severe diffuse infiltrate of macrophages and neutrophils in the lumen of the alveoli and bronchioles, accompanied by a large quantity of basophilic oval to piriform structures. These were suggestive of cysts and tachyzoites of $T$. gondii, which were free, or surrounded by a capsule, or inside intralesional macrophages (Figure 1B). Multifocal moderate hyperplasia of the bronchial and bronchiolar epithelium and hypertrophy of the smooth musculature of the alveolar wall were also observed.

In the liver, there was mild multifocal fibrinoid necrosis with a small quantity of free cysts and tachyzoites of $T$. gondii. The spleen presented hyperplasia of lymphoid follicles with rare cysts of T. gondii. In the mediastinal lymph node, there was diffuse infiltrate of macrophages in the capsular sinus and medullary region with severe erythrophagocytosis.

The bone marrow presented total absence of adipocytes, whereas there was strong predominance of cells of granulocytic lineage, forming parenchyma of high cellular heterogeneity, in which no organized or delimited erythroblast cell colonies were observed (this cell type was already scarce). Many of the blastic granulocytic cells

Table 1. Hemathological values from a cat with fatal toxoplasmosis associated with infection by the feline leukemia virus (FeLV).

\begin{tabular}{lccc}
\hline \multicolumn{1}{c}{ Parameters } & Cat values & Reference range* & Conclusion $^{*}$ \\
\hline Erythrocytes $\left(\mathrm{x} 10^{6}\right)$ & 7.37 & $5.0-10$ & WNR $^{*}$ \\
Hemoglobin $(\mathrm{g} / \mathrm{dL})$ & 10.8 & $8.0-15.0$ & WNR \\
Hematocrit $(\%)$ & 35 & $24-45$ & WNR \\
Mean corpuscular volume $(\mathrm{fL})$ & 47.5 & $39-55$ & WNR \\
Mean corpuscular hemoglobin concentration $(\%)$ & 30.9 & $31-35$ & WNR \\
Platelets $\left(\mathrm{x} 10^{3}\right)$ & 414 & $300-800$ & WNR \\
Total plasma protein $(\mathrm{g} / \mathrm{dL})$ & 6.8 & $6.0-8.0$ & WNR \\
Total leukocytes $(/ \mu \mathrm{L})$ & 5350 & $5500-19500$ & Decreased \\
Band neutrophils $(/ \mu \mathrm{L})$ & 0 & $0-300$ & WNR \\
Segmented neutrophils $(/ \mu \mathrm{L})$ & 4441 & $2500-12500$ & WNR \\
Lymphocytes $(/ \mu \mathrm{L})$ & 856 & $1500-7000$ & Decreased \\
Eosinophils $(/ \mu \mathrm{L})$ & 54 & $0-1500$ & WNR \\
Monocytes $(/ \mu \mathrm{L})$ & 0 & $0-850$ & WNR \\
Basophils $(/ \mu \mathrm{L})$ & 0 & rare & Decreased \\
\hline
\end{tabular}

${ }^{*}$ Feldman et al. (2000); "Within Normal Range. 

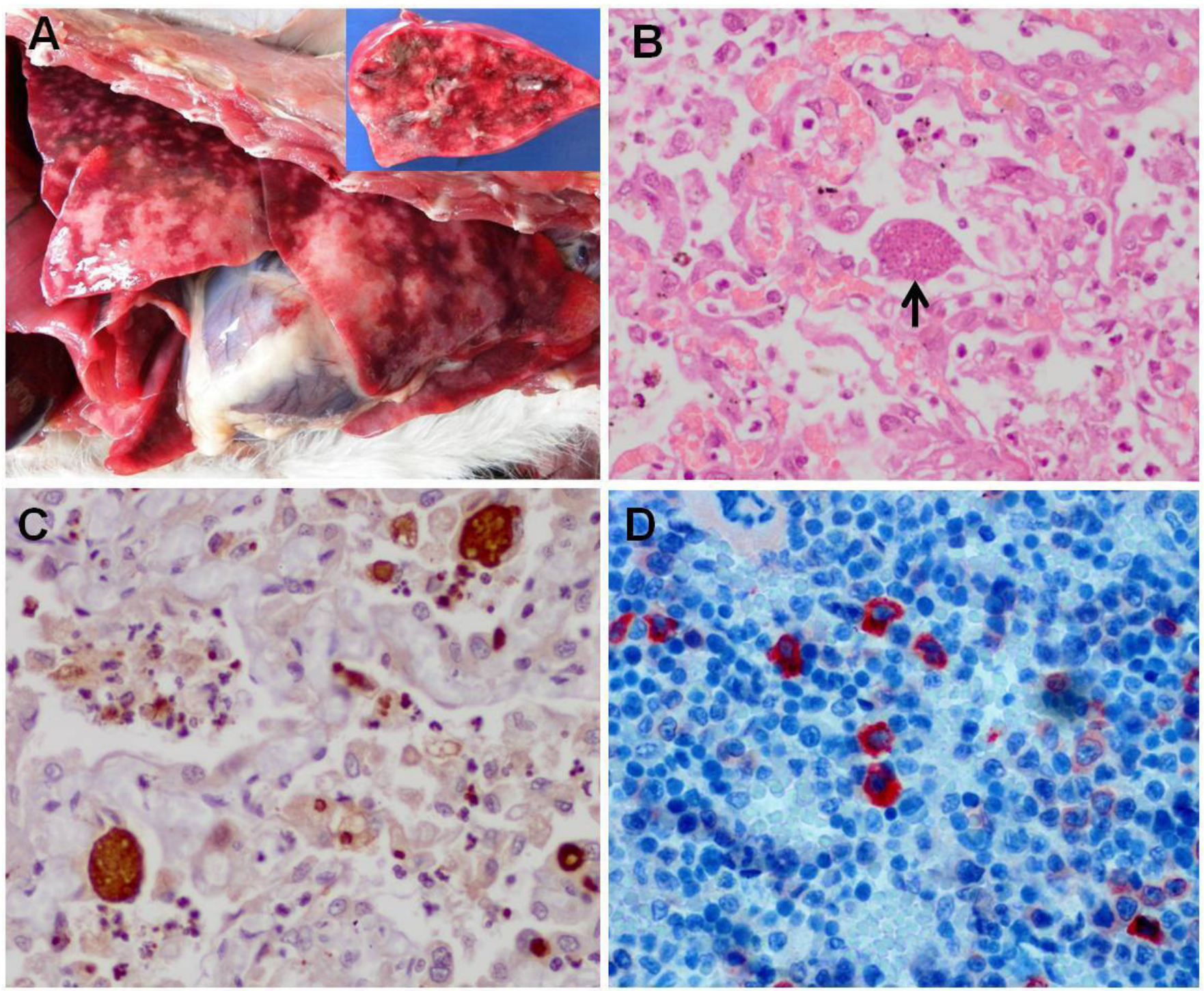

Figure 1. Toxoplasmosis in a cat. A: Non-collapsed lung tissue showing many white areas interspersed with reddened areas. In the detail, the cut surface. B: Interstitial pneumonia associated with Toxoplasma gondii cyst (arrow). HE; obj 40x. C: Anti-T. gondii-positive immunohistochemical evaluation on cysts and tachyzoites in lung tissue. Streptavidine-biotine ligated to peroxidase; obj 40x. D: Anti-FeLV-positive immunohistochemical evaluation on neoplastic bone marrow cells. Streptavidine-biotine ligated to phosphatase; obj 40x.

showed slight nuclear polymorphism, with moderate quantities of atypical megakaryocytes, without nuclear multilobulation, and smaller numbers of micromegakaryocytes that sometimes formed small groupings dispersed throughout the parenchyma. Around two to three typical and atypical mitoses were observed for every ten high-magnification (40x) fields. These neoplastic cells were seen to infiltrate the lymph nodes and portal region of the liver.

In the anti-T. gondii IHC examination, there was intense positive marking of cysts and tachyzoites relating to inflammatory foci inside the pulmonary alveoli (Figure 1C). The anti-FeLV IHC examination on the bone marrow was positive in the neoplastic cells (Figure 1D) and the anti-FIV examination was negative. Through the anatomopathological and IHC findings, the conclusion was a diagnosis of severe diffuse necrotic interstitial bronchopneumonia due to toxoplasmosis, associated with chronic myeloid leukemia due to FeLV. It was not possible to determine whether the cat was primarily immunocompromised due to other causes.

Lung fragments from the cat were $T$. gondii-positive according to REP-529 PCR. This strain was called PS-TgCatSCBr1. ToxoDB-PCR-RFLP \#10, i.e. the archetypal type I was identified. All the RFLP markers, including CS3, had type I alleles. However, through microsatellite analysis it could be seen that the strain identified was a variant of type I that showed atypical alleles with the typing markers B17 and M33 (Table 2). The neighbor-joining analysis based on microsatellite data showed that the strain PS-TgCatSCBr1 is divergent from the other reported Brazilian type I strains that have been reported and completely genotyped with MS markers (Figure 2). 
Table 2. Microsatellite genotyping of Toxoplasma gondii clonal type I genotype from a cat from Brazil and comparison with other reported type I isolates. Three reference archetypal strains (GT1, ME49 and NED) are included.

\begin{tabular}{|c|c|c|c|c|c|c|c|c|c|c|c|c|c|c|c|c|c|}
\hline \multirow[b]{2}{*}{ Isolate ID } & \multirow[b]{2}{*}{ MS Type $^{\#}$} & \multirow[b]{2}{*}{ Origin } & \multicolumn{15}{|c|}{ Microsatellite markers* } \\
\hline & & & $\stackrel{\S}{\circledR}$ & $\hat{n}$ & $\underset{i \infty}{i}$ & $\stackrel{\infty}{\infty}$ & $\widehat{\curvearrowright}$ & $\stackrel{n}{\xi}$ & $\grave{\lambda}$ & $\bar{\searrow}$ & $\stackrel{\infty}{\stackrel{\infty}{\Sigma}}$ & $\underset{\mathfrak{Z}}{\stackrel{z}{z}}$ & $\stackrel{8}{\gtrless}$ & $\stackrel{\infty}{\gtrless}$ & $\mathbb{F}$ & $\stackrel{\bar{b}}{z}$ & $\sum_{z}^{\infty}$ \\
\hline PS-TgCatBrSC1 ${ }^{\S}$ & I variant & Cat, southern Brazil & 291 & 248 & 209 & 160 & 334 & 167 & 274 & 358 & 223 & 166 & 145 & 129 & 269 & 087 & 306 \\
\hline $\operatorname{TgCkBr} 146^{a}$ & I & Chicken, southern Brazil & 291 & 248 & 209 & 160 & 342 & 169 & 274 & 358 & 211 & 166 & 147 & 121 & 265 & 087 & 306 \\
\hline $\mathrm{S} 11^{\mathrm{b}}$ & I variant & Pig, southern Brazil & 291 & 248 & 209 & 160 & 344 & 169 & 274 & 358 & 209 & 166 & 147 & 119 & 267 & 087 & 306 \\
\hline TgCatPr01 ${ }^{c}$ & I variant & Cat, Puerto Rico & 291 & 248 & 209 & 160 & 336 & 169 & 274 & 356 & 213 & 166 & 145 & 111 & 263 & 087 & 306 \\
\hline $\mathrm{HDC}^{\mathrm{e}}$ & $\mathrm{I}$ & Human, Colombia & 291 & 248 & 209 & 160 & 342 & 169 & 274 & 358 & 209 & 166 & 145 & 125 & 265 & 087 & 306 \\
\hline $\mathrm{TgCtCo07^{d }}$ & I & Cat, Colombia & 291 & 248 & 209 & 160 & 342 & 169 & 274 & 358 & 209 & 166 & 147 & 127 & 265 & 087 & 306 \\
\hline $\mathrm{MOR}^{\mathrm{e}}$ & I & Human, France & 291 & 248 & 209 & 160 & 342 & 169 & 274 & 358 & 209 & 166 & 147 & 119 & 265 & 087 & 306 \\
\hline GT1 & I & Goat, USA & 291 & 248 & 209 & 160 & 342 & 169 & 274 & 358 & 209 & 166 & 145 & 119 & 267 & 087 & 306 \\
\hline ME49 & II & Sheep, USA & 289 & 242 & 207 & 158 & 336 & 169 & 274 & 356 & 215 & 174 & 142 & 111 & 265 & 091 & 310 \\
\hline NED & III & Human, France & 289 & 242 & 205 & 160 & 336 & 165 & 278 & 356 & 209 & 190 & 147 & 111 & 267 & 091 & 312 \\
\hline
\end{tabular}

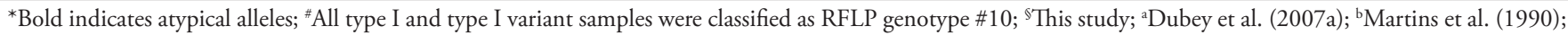
'Dubey et al. (2007b); ${ }^{\mathrm{d} D u b e y}$ et al. (2006); ${ }^{\mathrm{e}}$ personal communication.

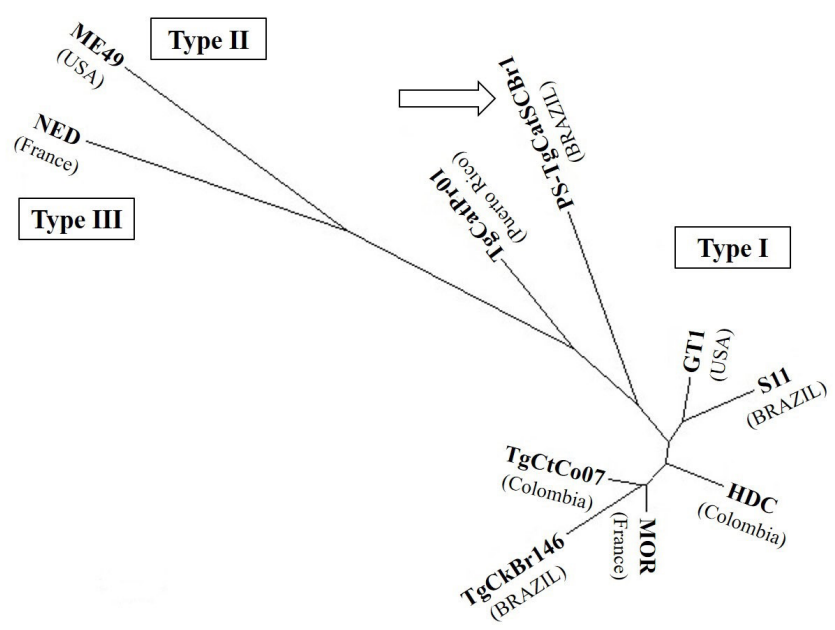

Figure 2. Neighbor-joining clustering of Toxoplasma gondii type I strains based on 15 microsatellite markers. Arrow is for the strain analyzed in the present study. Origin of isolates is also indicated. GT1, ME49 and NED are reference strains.

\section{Discussion}

Fatal clinical toxoplasmosis has been sporadically reported among cats. Studies conducted by Henriksen et al. (1994) and Jokelainen et al. (2012) demonstrated that 3.2\% (5/155) and 3.1\% (6/193) of the cats evaluated, respectively, died of toxoplasmosis.

In cats, after the intestinal phase of the infection, $T$. gondii tends to form cysts in various tissues, frequently in the liver, lungs, CNS, muscles and pancreas, and this is the main form of presentation in immunocompetent individuals (LAPPIN et al., 1989; LAPPIN, 2010). The acute form of the infection could be very important in immunocompromised cats, such as in those infected by FeLV and FIV (SVOBODOVÁ et al., 1998). In these, the cysts may become reactivated, thus making it possible for T. gondii to disseminate and cause disease (DAVIDSON et al.,
1993). In the present study, it is likely that the concomitant infection by FeLV contributed towards development of the disease, but it was not possible to determine whether the cat's infection was primary or whether it was a reactivation of latent infection. FeLV is a retrovirus that is known to cause several clinical syndromes, including immunosuppression, thereby facilitating opportunistic infections. This virus has the ability to cause thymus and bone marrow atrophy and, consequently, lymphopenia, neutropenia and depletion of CD4+ and CD8+ lymphocytes (OGILVIE et al., 1988; LUTZ et al., 2009). In the case reported here, increased lymphopenia was observed. Patton et al. (1991) reported that concurrent FeLV infection in experimentally infected cats did not interfere with the clinical outcome of T. gondii. However, differences in the ability of FeLV isolates to cause immunosuppression, or differences in T. gondii isolates, cannot be ruled out (OVERBAUGH et al., 1988).

The main clinical signs encountered related to the respiratory system, which is one of the main sites for dissemination of $T$. gondii (HARTMANN et al., 2013). The presentation and magnitude of the clinical signs will depend on the location and degree of tissue destruction caused by dissemination of the protozoon (LAPPIN et al., 1989; LAPPIN, 2010; COHEN et al., 2016). This explains the severe respiratory signs manifested by this cat, which were caused by severe diffuse necrotic bronchopneumonia. Furthermore, toxoplasmosis may present nonspecific signs such as fever, depression, anorexia and weight loss to varying degrees (HARTMANN et al., 2013; COHEN et al., 2016). These signs were also presented by the cat studied here.

The definitive diagnosis was obtained after the patient's death, by means of histopathological analysis, like in most other cases that have been reported (HENRIKSEN et al., 1994; LAST et al., 2004; SPYCHER et al., 2011; JOKELAINEN et al., 2012; NAGEL et al., 2013; COHEN et al., 2016). However, cytological analysis on the bronchoalveolar lavage to directly detect tachyzoites might have elucidated the clinical case (HARTMANN et al., 2013). In the necropsy, the main macroscopic lesion seen was pulmonary consolidation. This was also the most significant lesion observed in these other reports and also in an experimental study on cats 
with coinfection caused by FIV (DAVIDSON et al., 1993). Lymphadenomegaly and splenomegaly, which were seen in the present case, are also frequent lesions in cases of feline toxoplasmosis (DAVIDSON et al., 1993; HENRIKSEN et al., 1994; LAST et al., 2004; SPYCHER et al., 2011; JOKELAINEN et al., 2012; COHEN et al., 2016).

The main histological lesions in the present case were necrotic interstitial pneumonia and necrotic hepatitis, which were similar to the lesions described in the reports from the authors cited above. However, in some cases, necrosis was described in the spleen and lymph nodes, along with myocarditis, pancreatitis, adrenalitis, meningoencephalitis and uveitis (DAVIDSON et al., 1993; HENRIKSEN et al., 1994; LAST et al., 2004; SPYCHER et al., 2011; JOKELAINEN et al., 2012; NAGEL et al., 2013; COHEN et al., 2016). These lesions were not observed in the present study.

The diagnosis of toxoplasmosis in the present case was confirmed by means of IHC and PCR analysis. With HE staining, cysts and tachyzoites could be seen, especially in the lung tissue, which was found to be positive in anti-T. gondii IHC analysis.

The clinical outcome of toxoplasmosis depends on a variety of factors relating to the infectious agent and to the host. Among these, the host's immune status and genetic factors relating to host susceptibility and resistance stand out, along with the inoculum dose of the parasite, its infective stage and the genetic background of the parasite strain (MAUBON et al., 2008). It is unclear whether the strain of T. gondii that was identified as type I contributed to the severity of toxoplasmosis in this immunosuppressed cat. Khan et al. (2005) genotyped T. gondii strains from human immunodeficiency virus-positive patients and found high prevalence of type I strains or strains with type I alleles.

Among hundreds of isolates already genotyped in Brazil by means of PCR-RFLP (taking successful genotyping to relate to at least 10 markers), type I had only previously been isolated also in southern Brazil, from a chicken from the state of Rio Grande do Sul (DUBEY et al., 2007a) and from a pork sausage intended for human consumption, in the same state (MARTINS et al., 1990), in the southern Brazil. This region of Brazil is one of the regions with fewer strains genotyped, most studies have been conducted in the southeastern region, where the non-archetypal Brazilian clonal genotypes BrI, BrII and BrIII predominate (PENA et al., 2008; SHWAB et al., 2014). There is no information on $T$. gondii genotypes circulating in the state of Santa Catarina, but genotyping of $T$. gondii strains in the states of Rio Grande do Sul and Paraná, which are in the same southern region, have shown the predominance of non-archetypal genotypes and the great diversity that is characteristic of mainland areas of Brazil (SHWAB et al., 2014).

Shwab et al. (2014) reviewed the geographical patterns of T. gondii diversity by means of PCR-RFLP based on almost 1,500 samples that had already reported from Africa, Asia, Europe, Central/South America and North America. They showed that genotype type I (\#10) was the tenth most frequently identified type, accounting for $2.1 \%$ of the samples (originating from cats, chickens, humans, cows, pigs and tree sparrows). This genotype was most prevalent in East Asia and absent in Africa. It was interesting that while PCR-RFLP showed a typical type I clonal profile, microsatellite analysis (which has higher genotyping resolution) revealed atypical alleles in two typing markers, thus emphasizing the diversity of this parasite in Brazil.

For the first time in Brazil, this genotype was correlated with clinical disease in a host. Genotype characterization of T. gondii in all cases of toxoplasmosis from different hosts and regions will contribute towards knowledge of the epidemiology of this parasite.

\section{Acknowledgements}

This study was supported by the Coordination Office for Improvement of Higher Education Personnel (CAPES/PROEX, Brazil, grant 1841/2016).

\section{References}

Afonso E, Thulliez P, Gilot-Fromont E. Transmission of Toxoplasma gondii in an urban population of domestic cats (Felis catus). Int J Parasitol 2006; 36(13): 1373-1382. PMid:16989836. http://dx.doi.org/10.1016/j. ijpara.2006.07.010

Ajzenberg D, Bañuls AL, Su C, Dumètre A, Demar M, Carme B, et al. Genetic diversity, clonality and sexuality in Toxoplasma gondii. Int $J$ Parasitol 2004; 34(10): 1185-1196. PMid:15380690. http://dx.doi. org/10.1016/j.ijpara.2004.06.007.

Ajzenberg D, Collinet F, Mercier A, Vignoles P, Dardé ML. Genotyping of Toxoplasma gondii isolates with 15 microsatellite markers in a single multiplex PCR assay. J Clin Microbiol 2010; 48(12): 4641-4645. PMid:20881166. http://dx.doi.org/10.1128/JCM.01152-10.

Bernsteen L, Gregory CR, Aronson LR, Lirtzman RA, Brummer DG. Acute toxoplasmosis following renal transplantation in three cats and a dog. J Am Vet Med Assoc 1999; 215(8): 1123-1126. PMid:10530326.

Cavalli-Sforza LL, Edwards AWF. Phylogenetic analysis: models and estimation procedures. Am J Hum Genet 1967; 19(3): 233-257. PMid:6026583.

Cohen TM, Blois S, Vince AR. Fatal extraintestinal toxoplasmosis in a young male cat with enlarged mesenteric lymph nodes. Can Vet J 2016; 57(5): 483-486. PMid:27152033.

Cruz MA, Ullmann LS, Montaño PY, Hoffmann JL, Langoni H, Biondo AW. Seroprevalence of Toxoplasma gondii infection in cats from Curitiba, Paraná, Brazil. Rev Bras Parasitol Vet 2011; 20(3): 256-258. PMid:21961760. http://dx.doi.org/10.1590/S1984-29612011000300016.

Davidson MG, Rottman JB, English RV, Lappin MR, Tompkins MB. Feline immunodeficiency virus predisposes cats to acute generalized toxoplasmosis. Am J Pathol 1993; 143(5): 1486-1497. PMid:8238262.

Dorny P, Speybroeck N, Verstraete S, Baeke M, Becker A, Berkvens D, et al. Serological survey of Toxoplasma gondii, feline immunodeficiency virus and feline leukaemia virus in urban stray cats in Belgium. Vet Rec 2002; 151(21): 626-629. PMid:12479298. http://dx.doi.org/10.1136/ vr.151.21.626.

Dubey JP, Su C, Cortés JA, Sundar N, Gomez-Marin JE, Polo LJ, et al. Prevalence of Toxoplasma gondii in cats from Colombia, South America and genetic characterization of T. gondii isolates. Vet Parasitol 2006; 141(1-2): 42-47. PMid:16797845. http://dx.doi.org/10.1016/j.vetpar.2006.04.037.

Dubey JP, Sundar N, Gennari SM, Minervino AH, Farias NA, Ruas $\mathrm{JL}$, et al. Biologic and genetic comparison of Toxoplasma gondii isolates 
in free-range chickens from the northern Pará state and the southern state Rio Grande do Sul, Brazil revealed highly diverse and distinct parasite populations. Vet Parasitol 2007a; 143(2): 182-188. PMid:16982151. http://dx.doi.org/10.1016/j.vetpar.2006.08.024

Dubey JP, López-Torres HY, Sundar N, Velmurugan GV, Ajzenberg D, Kwok OC, et al. Mouse-virulent Toxoplasma gondii isolated from feral cats on Mona Island, Puerto Rico. J Parasitol 2007b; 93(6): 1365-1369. PMid:18314681. http://dx.doi.org/10.1645/GE-1409.1.

Dubey JP, Lappin MR, Kwok OCH, Mofya S, Chikweto A, Baffa A, et al. Seroprevalence of Toxoplasma gondii and concurrent Bartonella spp., feline immunodeficiency virus, and feline leukemia virus infections in cats from Grenada, west indies. J Parasitol 2009; 95(5): 1129-1133. PMid:19385716. http://dx.doi.org/10.1645/GE-2114.1.

Dubey JP. Toxoplasmosis of animals and humans. 2nd ed. Florida: Boca Raton; 2010.

Feldman BF, Zinkl JG, Jain CN. Schalm's veterinary hematology. 5th ed. Philadelphia: Lippincott Williams \& Wilkins; 2000.

Gajria B, Bahl A, Brestelli J, Dommer J, Fischer S, Gao X, et al. ToxoDB: an integrated Toxoplasma gondii database resource. Nucleic Acids Res 2007; 36: 553-556. PMid: 18003657. https://doi.org/10.1093/nar/gkm981.

Gonçalves E No, Munhoz AD, Albuquerque GR, Lopes CWG, Ferreira AMR. Ocorrência de gatos soropositivos para Toxoplasma gondii Nicolle e Manceaux, 1909 (Apicomplexa: Toxoplasmatinae) na cidade de Niterói, Rio de Janeiro. Rev Bras Parasitol Vet 2003; 12(4): 145-149.

Hartmann K, Addie D, Belák S, Boucraut-Baralon C, Egberink H, Frymus T, et al. Toxoplasma gondii infection in cats: ABCD guidelines on prevention and management. J Feline Med Surg 2013; 15(7): 631637. PMid:23813830. http://dx.doi.org/10.1177/1098612X13489228.

Henriksen P, Dietz HH, Henriksen SA. Fatal toxoplasmosis in five cats. Vet Parasitol 1994; 55(1-2): 15-20. PMid:7886915. http://dx.doi. org/10.1016/0304-4017(94)90052-3.

Homan WL, Vercammen M, de Braekeleer J, Verschueren H. Identification of a 200- to 300-fold repetitive 529 bp DNA fragment in Toxoplasma gondii, and its use for diagnostic and quantitative PCR. Int J Parasitol 2000; 30(1): 69-75. PMid:10675747. http://dx.doi.org/10.1016/S00207519(99)00170-8.

Howe DK, Sibley LD. Toxoplasma gondii comprises three clonal lineages: correlation of parasite genotype with human disease. J Infect Dis 1995; 172(6): 1561-1566. PMid:7594717. http://dx.doi.org/10.1093/ infdis/172.6.1561.

Jokelainen P, Simola O, Rantanen E, Näreaho A, Lohi H, Sukura A. Feline toxoplasmosis in Finland: cross-sectional epidemiological study and case series study. J Vet Diagn Invest 2012; 24(6): 1115-1124. PMid:23012380. http://dx.doi.org/10.1177/1040638712461787.

Khan A, Su C, German M, Storch GA, Clifford DB, Sibley D. Genotyping of Toxoplasma gondii strains from immunocompromised patients reveals high prevalence of type I strains. J Clin Microbiol 2005; 43(12): 5881-5887. PMid:16333071. http://dx.doi.org/10.1128/JCM.43.12.5881-5887.2005.

Kumar S, Stecher G, Tamura K. MEGA7: molecular evolutionary genetics analysis version 7.0 for bigger datasets. Mol Biol Evol 2016; 33(7): 18701874. PMid: 27004904. http://dx.doi.org/10.1093/molbev/msw054.

Langella O. Populations 1.2.31 [online]. Boston: Free Software Foundation; 1999 [cited 2017 Mar 30]. Available from: http://bioinformatics.org/ populations
Lappin MR, Greene CE, Winston S, Toll SL, Epstein ME. Clinical feline toxoplasmosis: serologic diagnosis and therapeutic management of 15 cases. J Vet Intern Med 1989; 3(3): 139-143. PMid:2778747. http:// dx.doi.org/10.1111/j.1939-1676.1989.tb03089.x.

Lappin MR. Update on the diagnosis and management of Toxoplasma gondii infection in cats. Top Companion Anim Med 2010; 25(3): 136141. PMid:20937495. http://dx.doi.org/10.1053/j.tcam.2010.07.002.

Last RD, Suzuki Y, Manning T, Lindsay D, Galipeau L, Whitbread TJ. A case of fatal systemic toxoplasmosis in a cat being treated with cyclosporin A for feline atopy. Vet Dermatol 2004; 15(3): 194-198. PMid:15214957. http://dx.doi.org/10.1111/j.1365-3164.2004.00371.x.

Lehmann T, Marcet PL, Graham DH, Dahl ER, Dubey JP. Globalization and the population structure of Toxoplasma gondii. Proc Natl Acad Sci USA 2006; 103(30): 11423-11428. PMid:16849431. http://dx.doi. org/10.1073/pnas.0601438103.

Lucas SRR, Hagiwara MK, Reche A Jr, Germano PML. Ocorrência de anticorpos antitoxoplasma em gatos infectados naturalmente pelo vírus da imunodeficiência dos felinos. Braz J Vet Res Anim Sci 1998; 35(1): 41-45. http://dx.doi.org/10.1590/S1413-95961998000100008.

Lutz H, Addie D, Belák S, Boucraut-Baralon C, Egberink H, Frymus T, et al. Feline leukaemia: ABCD guidelines on prevention and management. $J$ Feline Med Surg 2009; 11(7): 565-574. PMid:19481036. http://dx.doi. org/10.1016/j.jfms.2009.05.005.

Martins C, Silveira C, Jamra LMF, Barros PM, Belfort R Jr, Rigueiro MP, et al. Isolamento de Toxoplasma gondii de carnes e derivados, provenientes de região endêmica de toxoplasmose ocular-Erechim-RS. Arq Bras Oftalmol 1990; 53(1): 60-66.

Maubon D, Ajzenberg D, Brenier-Pinchart MP, Dardé ML, Pelloux H. What are the respective host and parasite contributions to toxoplasmosis? Trends Parasitol 2008; 24(7): 299-303. PMid:18514029. http://dx.doi. org/10.1016/j.pt.2008.03.012.

Nagel SS, Williams JH, Schoeman JP. Fatal disseminated toxoplasmosis in an immunocompetent cat. J S Afr Vet Assoc 2013; 84(1): 1-6. PMid:23718784. http://dx.doi.org/10.4102/jsava.v84i1.299.

National Center for Biotechnology Information - NCBI. [online]. Bethesda: NCBI; 1988 [cited 2017 Mar 30]. Available from: https:// www.ncbi.nlm.nih.gov/

Ogilvie GK, Tompkins MB, Tompkins WA. Clinical and immunologic aspects of FeLV-induced immunosuppression. Vet Microbiol 1988; 17(3): 287-296. PMid:2847393. http://dx.doi.org/10.1016/03781135(88)90070-3.

Overbaugh J, Donahue PR, Quackenbush SL, Hoover EA, Mullins JI. Molecular cloning of a feline leukemia virus that induces fatal immunodeficiency disease in cats. Science 1988; 239(4842): 906-910. PMid:2893454. http://dx.doi.org/10.1126/science.2893454.

Patton S, Legendre AM, McGavin MD, Pelletier D. Concurrent infection with Toxoplasma gondii and feline leukemia virus antibody response and oocyst production. J Vet Intern Med 1991; 5(3): 199-201. PMid:1920257. http://dx.doi.org/10.1111/j.1939-1676.1991.tb00948.x.

Pena HFJ, Gennari SM, Dubey JP, Su C. Population structure and mousevirulence of Toxoplasma gondii in Brazil. Int J Parasitol 2008; 38(5): 561 569. PMid:17963770. http://dx.doi.org/10.1016/j.ijpara.2007.09.004.

Pena HFJ, Soares RM, Amaku M, Dubey JP, Gennari SM. Toxoplasma gondii infection in cats from Sáo Paulo state, Brazil: seroprevalence, oocyst shedding, isolation in mice, and biologic and molecular characterization. Res 
Vet Sci 2006; 81(1): 58-67. PMid:16289158. http://dx.doi.org/10.1016/j. rvsc.2005.09.007.

Rosa LD, Moura AB, Trevisani N, Medeiros AP, Sartor AA, Souza AP, et al. Toxoplasma gondii antibodies on domiciled cats from Lages municipality, Santa Catarina State, Brazil. Rev Bras Parasitol Vet 2010; 19(4): 268-269. PMid:21184709. http://dx.doi.org/10.1590/S1984-29612010000400017.

Science Direct [online]. Elsevier BV; 2017 [cited 2017 Mar 30]. Available from: http://www.sciencedirect.com

Shwab EK, Zhu XQ, Majumdar D, Pena HFJ, Gennari SM, Dubey JP, et al. Geographical patterns of Toxoplasma gondii genetic diversity revealed by multilocus PCR-RFLP genotyping. Parasitology 2014; 141(4): 453-461. PMid:24477076. http://dx.doi.org/10.1017/S0031182013001844.
Spycher A, Geigy C, Howard J, Posthaus H, Gendron K, Gottstein $\mathrm{B}$, et al. Isolation and genotyping of Toxoplasma gondii causing fatal systemic toxoplasmosis in an immunocompetent 10 -year-old cat. $J$ Vet Diagn Invest 2011; 23(1): 104-108. PMid:21217037. http://dx.doi.org /10.1177/104063871102300117.

Su C, Shwab EK, Zhou P, Zhu XQ, Dubey JP. Moving towards an integrated approach to molecular detection and identification of Toxoplasma gondii. Parasitology 2010; 137(1): 1-11. PMid:19765337. http://dx.doi. org/10.1017/S0031182009991065.

Svobodová V, Knotek Z, Svoboda M. Prevalence of IgG and IgM antibodies specific to Toxoplasma gondii in cats. Vet Parasitol 1998; 80(2): 173-176. PMid:9870370. http://dx.doi.org/10.1016/S03044017(98)00201-5. 